\title{
New Particle Formation at a High Altitude Site in India: Impact of Fresh Emissions and Long Range Transport
}

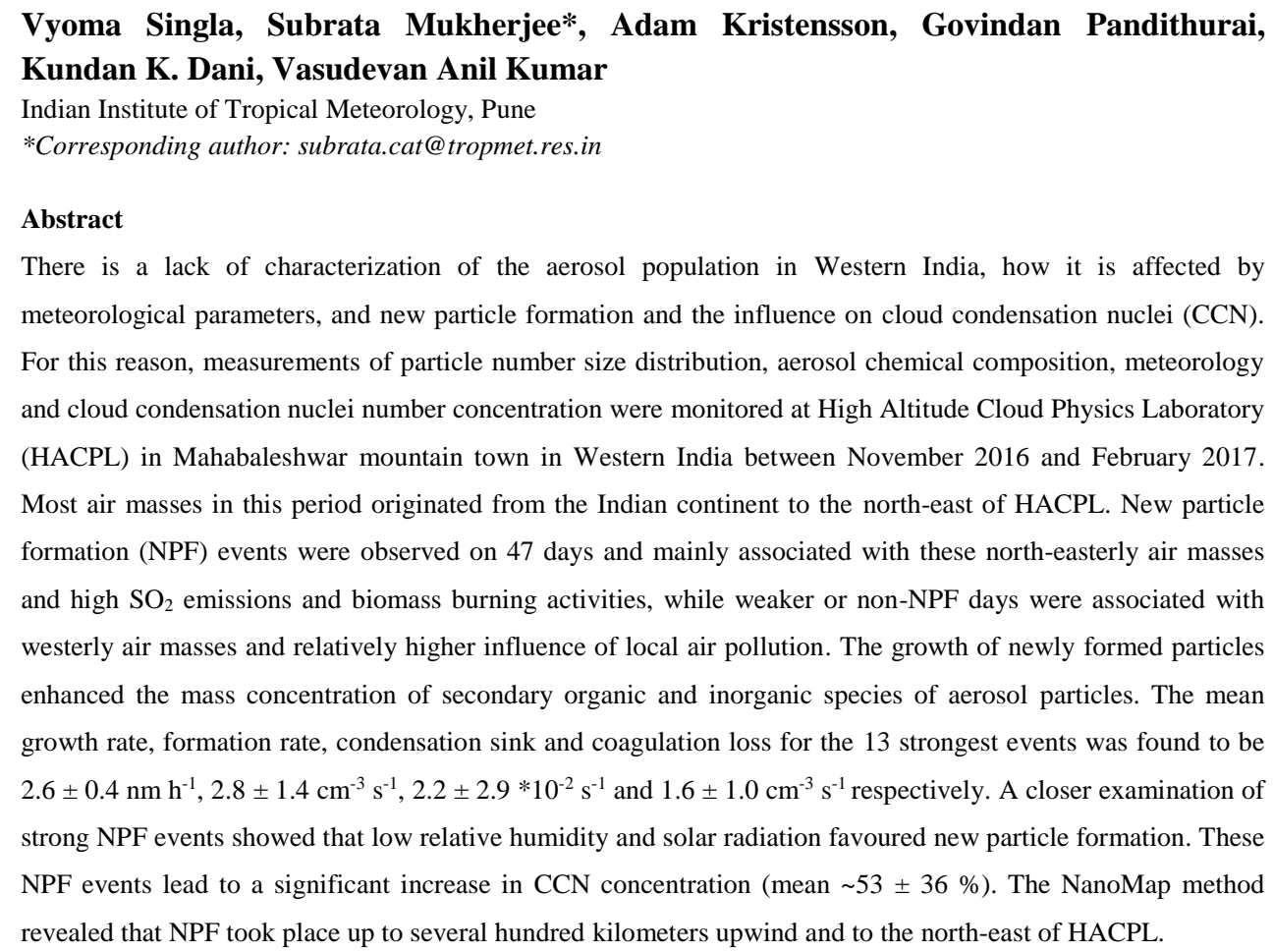

\section{Introduction}

Atmospheric aerosols directly affect the global climate by altering the radiative balance of the Earth atmosphere system (Stier et al., 2007) and indirectly by altering the cloud properties (Fan et al., 2012). However, these effects depend on the particle number size distribution and chemical composition of aerosol particles. Recent studies have shown that particle size is more important than the chemical composition in cloud formation (Dusek et al., 2006; Rose et al., 2010). The particles in the upper Aitken mode (>50 nm diameter) and in the accumulation mode $(100-1000 \mathrm{~nm})$ have a substantial effect on the cloud properties and initiation of precipitation as cloud condensation nuclei (Rosenfeld et al., 2008). Further, the number concentration of accumulation mode particles is related to visibility degradation (See et al., 2006), and sub-micron particles with health related problems (Seaton and Denekamp, 2003).

New particle formation (NPF) is one of the major sources of sub-micron particles in the atmosphere. It is characterized by a significant enhancement in the number concentration of nucleation mode particles and subsequent growth of these nucleated particles due to condensation (Kulmala and Kerminen, 2008; Skrabalova et al., 2015). Typical formation rates (FR) of $3 \mathrm{~nm}$ particles are in the range $0.01-10 \mathrm{~cm}^{-3} \mathrm{~s}^{-1}$ and typical growth 
41

rates (GR) in the range1-20 $\mathrm{nm} \mathrm{h}^{-1}$, depending upon temperature, humidity, pressure, and availability of condensable vapours. In urban areas, FR is often higher $\sim 100 \mathrm{~cm}^{-3} \mathrm{~s}^{-1}$ and even higher in the coastal areas and industrial plumes $\sim 10^{7}-10^{5} \mathrm{~cm}^{-3} \mathrm{~s}^{-1}$ (Kulmala et al., 2004). The atmospheric observations and laboratory experiments have identified sulfuric acid and organics as the two important precursors of NPF (Riipinen et al., 2007; Barsanti et al., 2009). There is always a competition between the FR and GR of freshly nucleated particles and the condensation sink and coagulation sink with larger particles (Vehkamki and Riipinen, 2012). As a result of that, nucleation and Aitken mode particles smaller than $25 \mathrm{~nm}$ and between 25 and $100 \mathrm{~nm}$ diameter, respectively tend to have a shorter lifetime than accumulation mode particles between 0.1 and $1 \mu \mathrm{m}$ diameter. If the FR is large enough and the condensation and coagulation sinks low enough during NPF, these recently generated particles can survive long enough in the atmosphere to be transported over distances of several hundred kilometers, depending on the wind speed (Kivekas et al., 2016).

The measurements of particle number size distribution show that NPF events and growth are widespread (Kulmala et al., 2004; Kulmala and Kerminen, 2008; Gong et al., 2008; Yue et al., 2010). Many studies address the spatial scale of NPF events in which the horizontal scale of NPF extends from hundreds to thousands of kilometres (Kulmala et al., 2004; Stainer et al., 2004; Dal Maso et al., 2005; Yue et al., 2010, Kristenson et al., 2014). The spatial scale of NPF events help to identify the origin of nucleation mode particles (Nemeth and Salma, 2014; Väänänen et al., 2016; Shen et al., 2018). The newly formed particles become climatically important when they attain the size of $\sim 50 \mathrm{~nm}$ in diameter (Kerminen et al., 2012). The particles with diameter $\geq$ $50 \mathrm{~nm}$ tend to act as CCN and affect the cloud microphysical and optical properties (Fiore et al., 2012). Model studies show that NPF accounts for 5-50\% of the CCN number concentration in the boundary layer (Spracklen et al., 2008). A study by Wiedensohler et al.(2009) shows that the growing nucleation mode particles can contribute to about $80 \%$ of the CCN number concentration during special conditions with strong NPF in China. Several other studies report the significant enhancement in atmospheric CCN concentrations due to NPF events (Levin et al., 2012; Creamean et al., 2011; Yue et al., 2011; Pierce et al., 2012; Ma et al., 2016; de Espana et al., 2017). NPF is known to dominate the particle number concentrations in clean atmosphere as compared to anthropogenically influenced regions (Lihavainen, 2003). However, the detailed mechanism of nucleation, its growth and its connection with biogenic emissions, anthropogenic activities and atmospheric chemistry, and the global role for $\mathrm{CCN}$ is still uncertain.

In this study, we identify the NPF events by analyzing particle number size distribution (PNSD) data at HACPL, Mahabaleshwar between November 2016 and February 2017. The characteristics of PNSD, new particle formation rate (FR), growth rate (GR) and condensation sink (CS) are evaluated during the identified NPF events at HACPL. The role of meteorology and chemical composition of sub-micron non-refractory particulate matter $\left(\mathrm{NR}-\mathrm{PM}_{1}\right)$ during the growth of freshly nucleated particles is also analyzed. A cluster analysis is performed to identify the geographical source areas responsible for the observed NPF events. The spatial scale of NPF events and where the 1-2 nm diameter particles are formed around the station is also analyzed by using the NanoMap method (Kristensson et al., 2014). Finally, the measured CCN number concentration, PNSD (5.14-900 nm) and chemical composition of NR-PM 1 aerosol are used to evaluate the probable contribution of NPF to the total CCN concentration at the sampling site. 
81

\section{Methodology}

\subsection{Measurement Site}

Measurements were performed at HACPL $\left(17.92^{\circ} \mathrm{N}, 73.65^{\circ} \mathrm{E} ; 1378 \mathrm{~m}\right.$ above mean sea level), located in the Western Ghats mountain range in south-west India. The site is at the small hill town Mahabaleshwar, which is also a tourist attraction. The town is surrounded by dense vegetation and residential houses, hotels and a rural market. During the study period, the site was influenced by both, local and regional anthropogenic pollution depending on the meteorological conditions and timing of source activities (Mukherjee et al., 2018).

\subsection{Instrumentation}

The aerosol chemical composition, particle number concentration and cloud condensation nuclei (CCN) number concentration were measured by using Time of Flight - Aerosol Chemical Speciation Monitor (ToF-ACSM), Wide Range Aerosol Spectrometer (WRAS) and CCN counter (CCNC) respectively. Due to different temporal resolutions of these instruments, the data sets were averaged hourly for the analysis. The QA/QC procedure for ToF-ACSM can be found in Mukherjee et al. (2018) and for WRAS and CCNC in Singla et al. (2017). The meteorological conditions (Solar radiation (SR), surface temperature (T), relative humidity $(\mathrm{RH})$, wind speed (WS) and wind direction (WD)) were recorded using an Automatic Weather Station (AWS) at an interval of one minute.

\subsubsection{Time of Flight - Aerosol Chemical Speciation Monitor (ToF-ACSM)}

A detailed description, specific to our ACSM instrument, its operation and calibration procedure is discussed in our earlier work (Mukherjee et al., 2018). In brief, before the ACSM, we sample the particle-laden and particle free air alternatively and then focus the particle beam into ACSM through an aerodynamic lens. In the detection chamber, the non-refractory particle fraction vaporizes at $\sim 600^{\circ} \mathrm{C}$ and $\sim 10^{-7} \mathrm{mbar}$ and is subsequently ionized by the electron impaction $\left(\mathrm{E}_{\mathrm{kin}}=70 \mathrm{eV}\right.$ ) by a tungsten filament arranged perpendicular to the particle beam in the vaporization region. The ions are extracted by a set of ion optics and introduced into the TOF analyzer where they are orthogonally extracted and separated based on their mass-to-charge ratio. The lens system has almost $100 \%$ transmission at vacuum aerodynamic diameters between 150-450 nm (Liu et al., 2007). The collection efficiency is assumed to be 0.5 in this analysis.

\subsubsection{Wide-range aerosol spectrometer (WRAS)}

The aerosol particle number concentration (PNC) was measured as a function of particle size (range $\sim 5 \mathrm{~nm}$ to $32 \mu \mathrm{m}$ in 72 channels) at 4-minute interval by using WRAS (manufactured by Grimm, Germany). The detailed description and calibration procedure of WRAS can be found in Singla et al., 2017. The instrument is kept under air conditioning conditions for its running at constant temperature. The sampling probe features a Nafion dryer to reduce the humidity to $\sim 40 \%$, to avoid the effect of ambient humidity and to reduce the error in measuring diameter in the detection system. Although WRAS provides information in the size range of $5 \mathrm{~nm}-32 \mu \mathrm{m}$, we have used PNC in the size range of $5.14-900 \mathrm{~nm}$ only to identify the NPF events in this study.

\subsubsection{Cloud Condensation Nuclei Counter (CCNC)}


Our earlier work (Singla et al., 2017) gives the detailed description of the CCN counter used in this study. A similar procedure was followed for the calibration of CCNC as discussed in Singla et al., 2017. The CCN number concentration was monitored as a function of time and supersaturation (SS) using a single-column continuous flow stream wise thermal gradient CCN chamber (DMT CCNC-100; Lance et al., 2006; Roberts and Nenes, 2005). The instrument runs at a flow rate of $0.5 \mathrm{Lmin}^{-1}$ with a sheath-to-aerosol flow ratio of 10:1. The activated particles are subsequently sized using an optical particle counter (OPC) and counted as CCN in the diameter range of $0.75-10 \mu \mathrm{m}$. The instrument samples particles every second at five different SS $(0.1,0.3$, $0.5,0.7$ and $0.9 \%$ ). The $\mathrm{CCN}$ concentration at $0.1 \% \mathrm{SS}$ is measured for $10 \mathrm{~min}$ and $5 \mathrm{~min}$ each for every other SS. This gives one complete CCN SS spectra in half an hour. The CCN data was only used in the period when the temperature was stable at each SS level.

\section{Data Analysis}

\subsection{Parameters characteristic of NPF events}

The criteria prescribed by Dal Maso et al.(2005) have been used for classifying the NPF events. The parameters characteristic of NPF events - growth rate (GR), formation rate (FR), condensation sink (CS) and coagulation loss (Coag) were calculated following the methodology of Dal Maso et al.(2005). The FR of 5nm particles was calculated at the beginning of each event and is expressed as:

$$
J_{5}=\frac{d N_{5-25}}{d t}+F_{\text {coag }}+F_{\text {growth }}
$$

where $\mathrm{N}_{5-25}$ is the concentration of nucleation mode particles $\left(\mathrm{N}_{\text {nuc }}\right), \mathrm{F}_{\text {coag }}$ is the scavenging of particles due to coagulation of freshly nucleated particles and $\mathrm{F}_{\text {growth }}$ is the flux of particles growing out of the size range 5-25 $\mathrm{nm}$. This growing flux of particles is defined as:

$$
F_{\text {growth }}=\frac{1}{\Delta D p} \cdot G R_{5-25} \cdot N_{5-25}
$$

where $\Delta \mathrm{Dp}$ is the change in diameter of particle i.e. $25 \mathrm{~nm}-5 \mathrm{~nm}=20 \mathrm{~nm}$, in this case. $\mathrm{GR}_{5-25}$ is the growth rate of freshly nucleated particles in the size range $\sim 5-25 \mathrm{~nm}$. The GR was obtained by fitting a first-order polynomial to the geometric mean diameters (GMD) of the nucleation mode particles. It is defined as:

$$
G R_{5-25}=\frac{\Delta D p}{\Delta t}
$$

Here $\Delta D_{p}$ is the change in geometric mean diameter and $\Delta t$ is the time interval. Further, the coagulation loss term, $F_{\text {coag }}$ is defined as:

and

$$
\begin{gathered}
F_{\text {coag }}=N_{5-25 .} \operatorname{Coag}_{5-25} \\
\operatorname{Coag}_{5-25}=\sum_{j} K_{i j} N_{j}
\end{gathered}
$$



PNC in size bin ' $\mathrm{j}$ '. Here 'i' was represented by $8 \mathrm{~nm}$ diameter and 'j' was varied between 25 and $900 \mathrm{~nm}$ diameter. Following Seinfeld and Pandis, 2008, the coagulation coefficient was calculated as:

$$
K_{i j}=\frac{2 k T}{3 \mu} \frac{\left(D_{p i}+D_{p j}\right)^{2}}{\left(D_{p i} \times D_{p j}\right)}
$$

Here 'Dp' is the particle diameter, $k$ is the Boltzmann constant $\left(1.38 \times 10^{-19} \mathrm{~cm}^{2} \mathrm{~kg} \mathrm{~s}^{-1}\right), \mu$ is the viscosity of air $\left(1.81 \times 10^{-7} \mathrm{~kg} \mathrm{~cm}^{-1}\right)$ and $\mathrm{T}$ is the surface temperature in Kelvin. Next, the condensation sink was calculated based on the assumption that the properties of condensable vapors were similar to sulfuric acid, an important condensable gas for the condensational growth of nucleated particles (Kulmala et al., 2013). CS is defined as:

$$
C S=2 \pi \cdot D_{j} \cdot \sum_{j} \beta_{m j} \cdot d_{j} \cdot N_{j}
$$

where $\mathrm{D}$ is the diffusion coefficient for sulfuric acid $\sim 0.117 \mathrm{~cm}^{-2} \mathrm{~s}^{-1}$ (Gong et al., 2010) and $\beta_{\mathrm{mj}}$ is the size dependent transition correction factor. The number concentration of aerosol particles in the size range of 5-25 $\mathrm{nm}$ was used to estimate the FR and GR. The CS and $\mathrm{F}_{\text {coag }}$ were calculated using the entire PSND ( 5-900 nm). The units of FR, GR, CS and $\mathrm{F}_{\text {coag }}$ are $\mathrm{cm}^{-3} \mathrm{~s}^{-1}, \mathrm{~nm} \mathrm{~h}^{-1}, \mathrm{~s}^{-1}$ and $\mathrm{cm}^{-3} \mathrm{~s}^{-1}$ respectively.

\subsection{NanoMap}

The NanoMap method developed by Kristensson et al.(2014), aims at representing the spatial distribution of regional NPF events based on the meteorological backward trajectories and continuous PNSD measurements at a point station. NanoMap gives an estimation of where NPF takes place at the point of formation of $1.5 \mathrm{~nm}$ diameter particles up to at least $500 \mathrm{~km}$ distance upwind of the sampling site. This method is based on the assumption that the measured NPF is a regional event and takes place over the full area covered by the regional NPF event with the same nucleation start and end time. The NanoMap procedure follows four basic steps - (i) classification and identification of type I NPF events (ii) choosing the start and end time of particle formation at the lowest bin size (iii) determining the end of growth time i.e. the growth of newly formed particles can no longer be followed in size distribution spectrum and (iv) plotting of a geographical position of the NPF events based on the meteorological backward trajectories and selection made in steps i) to iii). The meteorological backward trajectories have been calculated using the HYSPLIT model and meteorology data input from $1^{\circ}$ resolution Global Data Assimilation System (GDAS, Draxler and Rolph, 2003).

NanoMap is intended both for short data set (months to a few years) and longer data sets (several years or longer, where even the probability of formation as a function of geographical region can be estimated). In this study, the dataset of four months (from November 2016 to February 2017) is used to explore where the events take place. The lowest detection limit diameter of WRAS is $5 \mathrm{~nm}$ and nucleated particles need some time to grow from the initial size of $1.5 \mathrm{~nm}$ (Kulmala et al., 2013). The time shift between the real time formation and observed time formation of particles was set to $1.5 \mathrm{~h}$ based on the reported mean GR $\left(\sim 2.58 \mathrm{~nm} \mathrm{~h}^{-1}\right)$ at the sampling site. Uncertainties related to event classification, selection of starting and ending times, simultaneous 
event assumption and trajectory uncertainty are not negligible for the NanoMap method (Kristensson et al., 2014).

\section{Results and Discussion}

The PNSD data measured during the study period were analyzed to identify the NPF events at HACPL. NPF events occurred on $\sim 40 \%$ of the measurement days (47 days out of 115 days). Of the total 47 NPF events, 13 events were identified as strong events and 34 events as weak events. The strong and weak events were classified based on the number concentration of nucleation mode particles during the event. The events with $\mathrm{N}_{\text {nuc }}$ concentration greater than $6.0 * 10^{3} \mathrm{~cm}^{-3}$ were referred to as strong NPF events and vice-versa. Out of these 47 NPF events, a strong event day (12 ${ }^{\text {th }}$ December 2016) was selected for a more detailed analysis. The sampling site was under a varying influence of regional pollution throughout the study period (Mukherjee et al., 2018). The characteristics of NPF were studied in terms of growth rate (GR), condensation sink (CS), formation rate $(\mathrm{FR})$ and coagulation $\left(\mathrm{F}_{\text {coag }}\right)$. The characteristics of the NPF day were compared with the non-NPF day $14^{\text {th }}$ December 2016. The role of meteorology and aerosol chemical composition on NPF was also evaluated. Further, the contribution of newly formed particles to $\mathrm{CCN}$ was evaluated.

\subsection{Characteristics of NPF and non-NPF Event}

Figure 1 gives the colorplot of size distribution of aerosol particles on $12^{\text {th }}$ and $14^{\text {th }}$ December. In general, the formation of new particles is governed by (i) precursor gases (ii) meteorological conditions like solar radiation, temperature, relative humidity and wind speed and (iii) condensation sink. Figure 2 gives the diurnal variation of different meteorological parameters on the NPF and non-NPF day. During the NPF day, there was a sharp decrease in PNC from $\sim 5.8 * 10^{3} \mathrm{~cm}^{-3}$ to $4.1 * 10^{3} \mathrm{~cm}^{-3}$ at 08:00 hrs. This decrease was related to an increase in the boundary layer height. The gradual increase in boundary layer height is believed to bring cleaner air from aloft to the ground, thereby lowering the CS to about $1.8^{*} 10^{-2} \mathrm{~s}^{-1}$ a few hours later. Under low CS conditions, a sudden enhancement in the concentration of $\mathrm{N}_{\text {nuc }}\left(\sim 1.3 * 10^{4} \mathrm{~cm}^{-3}\right)$ was observed at 11:00 hrs. The formation rate $\left(\mathrm{J}_{5}\right)$ of particles was calculated as $\sim 6.6 \mathrm{~cm}^{-3} \mathrm{~s}^{-1}$. The CS is a measure of the amount of surface of the pre-existing aerosol particles available for the semi-volatile gases to condense on to. Thus the low aerosol surface favoured accumulation of condensable species in the gas phase, which nucleated and grew the new particles. The formation of new particles was observed approximately 60-90 minutes later than the onset of photo-oxidation. This delay was likely due to the lower limit of WRAS $(5.14 \mathrm{~nm})$ where it takes some time for nucleated cluster particles at $1.5 \mathrm{~nm}$ diameter to grow to the detectable size at $5.14 \mathrm{~nm}$ ). This is also the reason why the representative value of CS in Table 1 at the onset of nucleation is chosen as one hour prior to the first observed nucleation by the WRAS at $5.14 \mathrm{~nm}$. During the nucleation process, high solar radiation (mean $\sim 437 \pm 31 \mathrm{Wm}^{-2}$ ), low relative humidity (mean $\sim 28 \pm 3 \%$ ) and low wind speed (mean $\sim 3 \pm 0.7 \mathrm{~ms}^{-1}$ ) were recorded. This hot and less humid condition tends to favour the enhancement of atmospheric nucleation (Hamed et al., 2011). According to Figure 1, the particles were continuously formed at $5 \mathrm{~nm}$ diameter for a minimum of 2 hours and then grew at a rate of $2.5 \mathrm{~nm} \mathrm{hr}^{-1}\left(12^{\text {th }} \mathrm{Dec}\right)$ to a median size of $40 \mathrm{~nm}$ in due course of approximately 6 hours. The growth of particles shifted in the particle size distribution from nucleation to an Aitken $\left(\mathrm{N}_{\text {ait }}\right)$ and/or accumulation $\left(\mathrm{N}_{\mathrm{acc}}\right)$ regime in the early morning of $13^{\text {th }}$ December (01:00 hrs). Similar type of nucleation events have been observed by other researchers (Dal Maso et al., 2005; Kulmala et al., 2004; Wu et al., 2007; Wang et 
al., 2013; Kanawade et al., 2014; Leena et al., 2016; de Espana et al., 2017; Li et al., 2017). The CS increased gradually during the event with its hourly averaged maximum $\left(4.9 * 10^{-2} \mathrm{~s}^{-1}\right)$ around 18:00 hrs, demonstrating that the photo-oxidation has caused the rapid production of condensable vapors (Figure S1). The diurnal variation of coagulation sink with its peak (hourly maximum $\sim 9 \mathrm{~cm}^{-3} \mathrm{~s}^{-1}$ ) at 13:00 hrs suggested the maximum coagulation removal of newly formed particles during this time period (Figure S1). The coagulation sink for other strong NPF days is reported as an average throughout the day \pm standard deviation in Table 1.

On the other hand, the non-NPF day $\left(14^{\text {th }}\right.$ December) tended to have particle size distribution without a peak in $\mathrm{N}_{\text {nuc }}$ and contained only $\mathrm{N}_{\text {ait }}$ and/or $\mathrm{N}_{\text {acc }}$ particles. The mean PNC during 11:00-16:00 hours was observed to be $6.6^{*} 10^{3} \pm 1.5^{*} 10^{3} \mathrm{~cm}^{-3}$ with the GMD calculated for the entire size distribution, varying between 45 to $80 \mathrm{~nm}$. During this period, high relative humidity (mean $\sim 86 \pm 4 \%$ ), high wind speed (mean $\sim 6 \pm 1 \mathrm{~ms}^{-1}$ ) and low solar radiation (mean $\sim 238 \pm 62 \mathrm{Wm}^{-2}$ ) was recorded. It is believed that high relative humidity (>80\%) tends to limit the availability of gaseous sulphuric acid (a key precursor for NPF formation) in ambient air and thus inhibits the formation of new particles (Hamed et al., 2011).

The ambition was to calculate NPF parameters only during days with strong NPF. From the 13 strong NPF event days, 3 of these had gaps in data for a few hours, and NPF parameters were not possible to calculate, and hence only 10 strong events have been analyzed for NPF parameters. For these 10 events, the growth rate of nucleation mode particles was found to be linear with an average growth rate of $2.6 \pm 0.4 \mathrm{~nm} \mathrm{hr}^{-1}$. The CS on NPF days was much lower than on non-NPF days $\left(\sim 4.2-4.4 * 10^{-2} \mathrm{~s}^{-1}\right)$. The characteristic parameters for all strong NPF events days and 2 non-NPF days (for reference) are summarized in Table 1.

\subsection{Role of aerosol chemical composition}

Figure 3 gives the diurnal variation of $\mathrm{N}_{\text {nuc }}$ concentration, volume concentration of Aitken mode particles and mass concentration of aerosol species for the strong NPF day during December 12, 2016. The role of these parameters during the nucleation process was studied by dividing the activity period into 3-time windows. The first window represents 09:30 to 11:00 hrs, which includes the formation of new particles. The window no. 2 from 11:00 to 13:30 hrs characterizes the increase in newly formed particles, and window no. 3 (13:30 to 18:00 hrs) represents the growth stage with an increase in volume concentration of Aitken mode particles and a decrease in $\mathrm{N}_{\text {nuc }}$ concentration. During the first time window, a considerable decrease in aerosol mass concentration coincided with the rising boundary layer height, which led to the dilution of pollutants. The $\mathrm{N}_{\text {nuc }}$ concentration and Aitken volume concentration were at a minimum during this window. Since the formation of new particles is governed by the nature of pre-existing aerosol particles, the particle acidity was evaluated by following the methodology of Engelhardt et al., 2013. The ratio of ammonium to anions (sulfate and nitrate) was calculated as 1.08 , which indicated the neutralized nature of aerosols. The neutralized aerosols make the atmospheric conditions favourable for NPF. On the other hand, the aerosols on non-NPF day (14 ${ }^{\text {th }}$ December) were found to be slightly acidic in nature with the ratio of ammonium to anions varying between 0.88 and 0.90 . Therefore it is assumed that the ammonium available in atmosphere would be used up by the pre-existing anions for their neutralization and thereby could potentially suppress the NPF (Pikridis et al., 2014). During window no. 2, a significant increase in the $\mathrm{N}_{\text {nuc }}$ concentration was observed. In the third time window, the gradual 
increase in Aitken volume concentration and decrease in $\mathrm{N}_{\text {nuc }}$ concentration was observed. This was accompanied by the gradual increase in mass concentration of aerosol (organics, sulfate, nitrate and ammonium), but with a time lag of $\sim 2$ hours. The ACSM is not able to detect the smallest particles in the Aitken mode range, but only after they have grown to detectable sizes a few hours later. The organic components OOA, HOA, BBOA all increase during the afternoon and evening and were identified on the basis of fragmentation patterns of the ACSM and source/receptor analysis of high resolution mass spectra using Positive Matrix Factorization (PMF) model (Paatero and Tapper, 1994). More details on PMF methodology used in this study are given in our earlier work (Mukherjee et al., 2018). OOA is the oxygenated organic aerosol and relates to secondary organic aerosol. HOA and BBOA refer to hydrocarbon-like organic aerosol and biomass burning organic aerosol. HOA and BBOA are the surrogates of primary organic aerosol. The gradual increase in aerosol mass concentration suggested that (i) the particle size has grown large enough ( $\geq 40 \mathrm{~nm}$ ) to be able to be detectable by the ACSM as explained earlier and (ii) that there is formation of secondary aerosol components during the growth of newly formed particles. It is believed that the production of low volatile organic vapours and nitrate have caused these new particles to grow quickly, thereby enhancing the CCN concentrations significantly (Figure 3e). Similar features have also been reported by previous NPF studies in diverse environments (Kulmala et al., 2004; Zhang et al., 2004; Crilley et al., 2014; Li et al., 2017).

\subsection{Contribution of NPF to CCN}

In order to become $\mathrm{CCN}$, the freshly nucleated particles must attain a minimum size of $\sim 40 \mathrm{~nm}$. To determine the probable contribution of these particles to $\mathrm{CCN}$, simultaneous measurements of $\mathrm{CCN}$ were carried out. Figure 3(e) gives the hourly variation of $\mathrm{CCN}$ concentration at five supersaturation levels on the NPF day. The $\mathrm{CCN}$ concentration increased gradually coinciding with the (i) increase in $\mathrm{N}_{\text {ait }}$ concentration, and (ii) increase in volume concentration of Aitken mode particles. This increase in $\mathrm{CCN}$ concentration was attributed to the increase in number concentration of particles fulfilling the size criteria for $\mathrm{CCN}$ formation. The probable contribution of newly formed particles to $\mathrm{CCN}$ formation was evaluated in terms of percent increase in $\mathrm{CCN}$. The percent increase was calculated by comparing the $\mathrm{CCN}$ concentrations before and after the nucleation event. The two time windows were selected as - "Window $1\left(\mathrm{~W}_{1}\right)$ and Window $2\left(\mathrm{~W}_{2}\right)$ " representing the time periods before and after the nucleation event respectively (Please see Figure 1). While choosing these windows, the care was taken to ensure that: (i) there were no primary emissions, (ii) meteorological conditions were sufficiently stable, and (iii) the geometric mean diameter (GMD) of particles was well above $40 \mathrm{~nm}$. In this study, primary organic aerosol $(\mathrm{POA}=\mathrm{HOA}+\mathrm{BBOA})$ was used as a marker for the primary emissions. The stable meteorological conditions were defined by stable wind speed and wind direction. Further it should be noted that for the days with successive NPF events, $\mathrm{W}_{1}$ was chosen just before the initiation of nucleation event. The second time window was selected when the GMD of aerosol particles was well above the $40 \mathrm{~nm}$. Thus the change in $\mathrm{CCN}$ concentration was calculated as:

$$
\Delta \mathrm{CCN}=\frac{\mathrm{CCN}_{\mathrm{W}_{2}}-\mathrm{CCN}_{\mathrm{W}_{1}}}{\mathrm{CCN}_{\mathrm{W}_{1}}}
$$


Table 2 gives the change in CCN concentration and other parameters for the 13 strong NPF events, which is $\sim 27 \%$ of all the events. These days are chosen on the basis of availability of all the simultaneous measurements (aerosol chemical composition, PNC and meteorological parameters) and the fulfillment of the requirements for the number concentration of strong events in section 4. The CCN measurements were selected at $0.52 \% \mathrm{SS}$ in this study, which would correspond to activation diameters around $70 \mathrm{~nm}$ for hygroscopic particles (Singla et al., 2017). A considerable increase in CCN concentrations was observed after the event on each day with an average increment of $42 \pm 27 \%$ (Table 2). In this study, POA (primary organic aerosol) was also used as a surrogate for BC (tracer for primary emission). The parameters - change in activated fraction and change in $\mathrm{CCN} / \mathrm{POA}$, were calculated to identify the source of increased $\mathrm{CCN}$ concentrations. If the change in activated fraction is similar to the change in CCN/POA, then primary emissions are the likely contributors for increased $\mathrm{CCN}$ concentrations. On the other hand, if the change in activated fraction differs from the change in CCN/POA, newly formed particles are the major contributors to increased CCN concentrations (de España et al., 2017). It is observed from Table 2 that the change in activated fraction differs significantly from the change in CCN/POA for each day. As an example, the metrics for $12^{\text {th }}$ December shows that, the change in CCN/CN is $26 \%$ and the change in CCN/POA is $-18 \%$. This significant difference (between W1 and W2, refer figure 1) indicated new particle formation as the important source of $\mathrm{CCN}$ at our site. The significant difference between $\Delta(\mathrm{CCN} / \mathrm{CN})$ and $\Delta(\mathrm{CCN} / \mathrm{POA})$ for all the chosen events suggested NPF as the distinct source of increased $\mathrm{CCN}$. Further, $\Delta\left(\mathrm{CCN} / \mathrm{NR}-\mathrm{PM}_{1}\right)$ was also calculated for accounting the BLH effect, if any. The positive change of $\triangle \mathrm{CCN} / \mathrm{NR}-\mathrm{PM}_{1}$ indicated that higher $\mathrm{CCN} / \mathrm{NR}-\mathrm{PM}_{1}$ after the event was the result of NPF and not the dilution of BLH.

\subsection{Cluster analysis}

The cluster analysis was carried out to outline the relationship of air masses with the observed particle number size distribution of aerosols. The trajectories were simulated by using the Hybrid Single-Particle Lagrangian Integrated Trajectory (HYSPLIT) model (Draxler and Rolph, 2003). The 120 hour backward trajectories were calculated for every hour terminating at a height of $100 \mathrm{~m}$ above the ground level. In total, 2760 trajectories were calculated during the study period. The transport pathways of the observed air masses were grouped into five clusters on the basis of total spatial variance (TSV). Each cluster congregated into different geographical origin(s). The air-mass backward trajectory calculations and cluster analysis were performed by using Zefir (Igor-based software developed by Petit et al., 2017). Before running the cluster analysis, backward trajectory data was down-weighted by using the discrete weighting function in Zefir (Petit et al., 2017).

Figure 4(a) shows the derived fire hotspots (good indicators for biomass burning activities), from MODIS (Moderate Resolution Imaging Spectro-radiometer) and geographical origin of each cluster and Figure 4(b) shows the corresponding PNSD observed at the receptor site. The PNSD of each cluster was constructed by averaging the particle number size distribution for each time step belonging to that particular cluster. It was observed that air masses arriving at the receptor site generally originated from the inland continent and represented $95 \%$ of the total back trajectories (cluster C1 - 51\%, cluster C2 - 13\% and cluster C3 - 25\%). Cluster C1 originated from Central India, C2 from northwest India and C3 from southeast India. On the other hand, clusters C4 and C5 began from Iran and Saudi Arabia respectively and contributed only 4\% and 7\% respectively 
to the total back trajectories. Before reaching the receptor site, cluster $\mathrm{C} 4$ traveled long through the land and cluster C5 traveled both through the sea and land. Both the clusters - C4 and C5 were identified as fast moving clusters. However, only cluster $\mathrm{C} 4$ was found to be a relatively cleaner air mass as the total $\mathrm{NR}^{-\mathrm{PM}} \mathrm{H}_{1}$ concentration for $\mathrm{C} 4$ was found to be $7.2 \mu \mathrm{gm}^{-3}$. On the other hand, continental originated clusters were identified as slow moving clusters and were associated with higher $\mathrm{PM}_{1}$ concentration $\left(\mathrm{C} 1 \sim 15 \mu \mathrm{gm}^{-3}, \mathrm{C}^{2} \sim 11\right.$ $\mu \mathrm{gm}^{-3}$ and $\mathrm{C} 3 \sim 13 \mu \mathrm{gm}^{-3}$ ). The results of PNSD showed that the formation and growth of nucleation mode particles were significant for clusters associated with continental air masses (Figure 4). Clusters (C4 and C5) did not contain any nucleation although the mean total particle number concentration was comparable. The characteristics of aerosol particles associated with each cluster were analyzed by dividing the PNC into 3 distinct modes - nucleation (5-25 nm), Aitken $(25-100 \mathrm{~nm})$ and accumulation $(100-1000 \mathrm{~nm})$ mode. The diurnal variation of PNC in these 3 modes for each cluster is shown in Figure S2.

Nucleation mode - The particles in this mode showed significant increase in number concentration from 11:00 to 15:00 hours for clusters $\mathrm{C} 1$ and $\mathrm{C} 2$ with the considerable decrease in $\mathrm{N}_{\text {ait }}$ concentration. This increase was mainly influenced by the formation and growth of new particles under favourable meteorological conditions. However, a faded increase in the number concentration was also observed for cluster C3 between 13:00 and 15:00 hours $\sim 1155 \mathrm{~cm}^{-3}$ ). This diminished nucleation was attributed to the interference caused by a sudden increase in $\mathrm{N}_{\text {ait }}$ concentration at the onset of nucleation. Thereafter, the nucleation event persisted for few hours. Conversely, no nucleation process was observed for clusters C4 and C5. The diurnal variation of $\mathrm{N}_{\text {nuc }}$ particles exhibited high concentration during morning, afternoon and evening hours. However, these $\mathrm{N}_{\text {nuc }}$ peaks coincided well with the $\mathrm{N}_{\text {ait }}$ concentration peaks. The simultaneous peaks in the two modes suggested the emission of nucleation particles directly by local sources.

Aitken mode - For all the air mass cluster types, the particles in this mode reflected a morning ( 08:00 hrs) and an evening ( 18:00 hrs) peak corresponding to traffic rush hours. In addition, clusters C3, C4 and C5 showed somewhat elevated concentrations during afternoon and early evening in the PNC. These peaks may be attributed to the fresh anthropogenic emissions by cooking related sources (Mukherjee et al., 2018). The mean PNC during the morning peak was $2.5^{*} 10^{3} \mathrm{~cm}^{-3}, 2.6^{*} 10^{3} \mathrm{~cm}^{-3}, 2.4^{*} 10^{3} \mathrm{~cm}^{-3}, 5.5^{*} 10^{3} \mathrm{~cm}^{-3}$ and $5.2^{*} 10^{3} \mathrm{~cm}^{-3}$ for clusters $\mathrm{C} 1, \mathrm{C} 2, \mathrm{C} 3, \mathrm{C} 4$ and $\mathrm{C} 5$ respectively. In addition, a significant noon peak related to cooking was observed for cluster C3 $\left(\sim 2663 \mathrm{~cm}^{-3}\right)$.

Accumulation mode - The PNC in this mode showed a stable pattern as a function of time for clusters C1, C2 and C3. This stable pattern of PNC indicated the regional transport of anthropogenic pollution to the receptor site. The regional transport of organics and sulfate has been reported during the same period in our earlier work (Mukherjee et al., 2018). The 24-hour average concentration of $\mathrm{N}_{\text {acc }}$ particles was measured as $1.8 * 10^{3} \mathrm{~cm}^{-3}$, $2.0^{*} 10^{3} \mathrm{~cm}^{-3}, 1.8 * 10^{3} \mathrm{~cm}^{-3}, 1.4 * 10^{3} \mathrm{~cm}^{-3}$ and $2.1 * 10^{3} \mathrm{~cm}^{-3}$ for clusters $\mathrm{C} 1, \mathrm{C} 2, \mathrm{C} 3, \mathrm{C} 4$ and $\mathrm{C} 5$ respectively.

The above analysis revealed that the clusters associated with continental air masses favoured new particle formation under the influence of long range transported anthropogenic pollution to the sampling site. However, the clusters associated with foreign air masses did not favour new particle formation. Based on the diurnal 
variation of $\mathrm{N}_{\text {nuc }}, \mathrm{N}_{\text {ait }}$ and $\mathrm{N}_{\text {acc }}$, it was assumed that the concentration of $\mathrm{N}_{\text {ait }}$ is influencing the occurence of NPF. It was noticed that the concentration of $\mathrm{N}_{\text {ait }}$ during the morning hours was well below $\sim 3 * 10^{3} \mathrm{~cm}^{-3}$ for continental clusters and much above $\sim 5.5 * 10^{3} \mathrm{~cm}^{-3}$ for the foreign clusters. Also, the nucleation process was found to be inhibited for cluster $\mathrm{C} 3$ by the sudden increase in $\mathrm{N}_{\text {ait }}$ concentration $\left(\sim 2.7 * 10^{3} \mathrm{~cm}^{-3}\right)$ during the afternoon hours. These statistics suggest that the number concentration of $\sim 3 * 10^{3} \mathrm{~cm}^{-3}$ may be acting as a threshold value of $\mathrm{N}_{\text {ait }}$ particles for the appearance of NPF. The concentration of $\mathrm{N}_{\text {ait }}$ below $\sim 3 * 10^{3} \mathrm{~cm}^{-3}$ was found to favour NPF at this site during the study period and vice versa. On the other hand, clusters 4 and 5 also show a decrease in $\mathrm{N}_{\text {ait }}$ after the morning period, and still NPF does not take place. This may be indicative of low addition of condensable vapours needed for NPF for the cluster 4 and 5 air masses, whereas it is likely that the addition of condensable vapours for NPF is high enough in the Clusters 1-3. The insight into the relationship between $\mathrm{N}_{\text {ait }}$ concentration and nucleation process was further comprehended by analyzing the individual days. As an example, three days - 12 $2^{\text {th }}$ Dec 2016, $19^{\text {th }}$ Dec 2016 and $19^{\text {th }}$ Nov 2016 were chosen as representative days for NPF, non NPF and weak NPF respectively. The selected days belongs to cluster C1. The cluster C1 was chosen because it contributed most $(\sim 51 \%)$ to the total back trajectories.

Figure 5 shows the diurnal variation of PNC in 3 modes $\left(\mathrm{N}_{\text {nuc }}, \mathrm{N}_{\text {ait }}\right.$ and $\left.\mathrm{N}_{\text {acc }}\right)$ for three selected days. The variation in meteorology - temperature (T), relative humidity (RH) and wind speed (WS) is shown in Figure S3. The PNC in the Aitken mode during 07:00 - 09:00 hrs was found to be $\sim 2.2 * 10^{3} \mathrm{~cm}^{-3}, \sim 3.6^{*} 10^{3} \mathrm{~cm}^{-3}$ and $\sim 2.6^{*} 10^{3} \mathrm{~cm}^{-3}$ on NPF, non-NPF and weak NPF day respectively for the three selected days. The variation of solar radiation and temperature was found to be similar on all the days. On the other hand, $\mathrm{RH}$ varied considerably. During the NPF day, the mean RH was $\sim 36 \pm 7 \%$ with the minimum of $\sim 23 \%$ during the nucleation process. The non-NPF and weak NPF day showed a mean RH of $\sim 57 \pm 4 \%$ and $\sim 26 \pm 7 \%$ respectively. The magnitude of WS was also variable. The NPF day, non-NPF day and weak NPF day showed mean WS of $6.2 \pm 2.8 \mathrm{~ms}^{-1}, 2.4 \pm 1.2 \mathrm{~ms}^{-1}$ and $4.1 \pm 1.6 \mathrm{~ms}^{-1}$. Further, high WS was recorded just before the nucleation event (08:00 to 09:00 hrs), $\sim 8.7 \mathrm{~ms}^{-1}$ on the NPF day, $\sim 1.7 \mathrm{~ms}^{-1}$ on the non-NPF day and $6.8 \mathrm{~ms}^{-1}$ (10:00 hrs) on the weak NPF day. On the basis of these statistics, it was concluded that stable, relatively low background Aitken mode concentrations with low RH favoured the new particle formation on $12^{\text {th }}$ December under high wind speed, temperature and solar radiation conditions. On the other hand, fresh anthropogenic emissions and unfavourable meteorological conditions inhibited the nucleation activity on $19^{\text {th }}$ December. The fresh anthropogenic emissions were observed during morning $\left(\sim 3.4^{*} 10^{3} \mathrm{~cm}^{-3}\right)$ and noon $\left(\sim 3.1^{*} 10^{3} \mathrm{~cm}^{-3}\right)$ on $19^{\text {th }}$ November as well. However, the $\mathrm{N}_{\text {ait }}$ concentration was much lower than that observed on the non-NPF day. Secondly, the molar ratio of ammonium to inorganic anions was calculated as $\sim 1.4$. Since both source (ammonia) and sink (pre-existing particles due to fresh anthropogenic emissions) entities were present in high amount, it was not likely inhibiting NPF as suggested in section 4.2. Instead, relatively unfavourable meteorological conditions inhibited strong formation on the weak NPF event day. Moreover, the interference by fresh emissions during noon time was assumed to suppress the nucleation activity and hence lead to the weak $\mathrm{NPF}$ day with maximum $\mathrm{N}_{\text {nuc }} \sim 4.5^{*} 10^{3} \mathrm{~cm}^{-3}$ at 15:00 hrs.

Since the nucleation process in this study was influenced by the transported anthropogenic pollution, the chemical composition of each cluster was also evaluated. Table 3 gives the mass concentration of organic and 
inorganic components of aerosol particles. The comparable mass concentration of nitrate and HOA indicated no influence of long range transport on NPF. The mass concentration of sulfate, ammonium, BBOA and OOA was higher for the continental clusters 1-3 as compared to the foreign clusters 4-5. This difference may be attributed to the travel pathways of each cluster. Clusters C4 and C5 were identified as fast moving clusters and had a lower travel time over the continent. Therefore, it was assumed that high mass concentration of sulfate, ammonium, BBOA and OOA were indicative of local or regional emissions. The continental clusters originated from the biomass burning affected areas and identified to represent regional, or in other words, long range transported aerosol particles (Figure 4). The higher mass concentration of BBOA was attributed to the regional transport of biomass burning related aerosols. With a reported lifetime of $3.8 \pm 0.8$ days (Edwards et al., 2006), biomass burning plumes are often transported for thousands of kilometers (Anderson et al., 1996; Andreae et al., 1988). The higher mass concentration of sulfate was also related to long range transport. Since no direct measurements of $\mathrm{SO}_{2}$ were available at this site, the spatial distribution of $\mathrm{SO}_{2}$ emissions over the Indian region was extracted from the OMI satellite (Figure S4). Figure S4 shows high $\mathrm{SO}_{2}$ emissions in central India. The biomass burning events and power plants seems to serve as the two major sources of $\mathrm{SO}_{2}$ emissions during the study period (Figure 4 and $\mathrm{S} 4$ ). It is reported that $\mathrm{NO}_{2}$ can act as an important oxidant for the conversion of $\mathrm{SO}_{2}$ to sulfate under biomass burning influenced anthropogenic pollution (Xie et al., 2015). Further, the continental clusters also displayed higher mass concentration of OOA. This high concentration was attributed to the atmospheric changes in biomass burning aerosols often resulting in the enhanced fraction of OOA and degradation of biomass burning related species (Cubison et al., 2011; DeCarlo et al., 2008; Yokelson et al., 2009). Therefore, it can be concluded that the formation of new particles took place under the influence of biomass burning affected anthropogenic pollution. The chamber study by Henningan et al., 2012 has shown that exposing the biomass burning plume to UV light initiates photo-oxidation thereby creating a strong nucleation burst. The field studies have also reported the nucleation activity in fresh (Hobbs et al., 2003) and aged fire plumes (Andreae et al., 2001; Wu et al., 2016).

\subsection{NanoMap}

The NanoMap method (Kristensson et al., 2014) was used to identify the spatial distribution of NPF events during the formation of $1.5 \mathrm{~nm}$ particle diameter. It is only applicable to the areas which are upwind and up to $500 \mathrm{~km}$ from the sampling site. This method helps in determining the spatial NPF events occurring at the same time as at the sampling site. In this study, the dataset of 4 months (November 2016 to February 2017) was used to earmark the source area and frequency of the formation of $1.5 \mathrm{~nm}$ diameter particles along the trajectories. The data was available for $95 \%$ of total days (115 days out of 120 days). During these days, 34\% of days ( 40 days) were identified as type-I NPF event days. All the events were easily analyzable with respect to start time of NPF and end of growth time.

Figure 6 shows the location of formation of $1.5 \mathrm{~nm}$ diameter upwind of the HACPL site with a grid resolution of $0.1 \times 0.2^{\circ}$. A large NPF frequency was observed in the areas favoured solely by the continental air masses. The biomass burning mixed anthropogenic plume from the Central India seems to favour the occurrence of the NPF events upwind of HACPL. However, no NPF events were registered with the air masses coming from other directions. The probable reason could be the non-availability of sufficient precursors $\left(\mathrm{SO}_{2} \mathrm{or}_{2} \mathrm{H}_{2} \mathrm{SO}_{4}\right)$ at the 
sampling site. Figure S4 shows the $\mathrm{SO}_{2}$ emission for the time period - November 2016 to February 2017. It has been reported that $\mathrm{SO}_{2}$ once emitted, readily reacts with hydroxyl radical in the atmosphere to produce $\mathrm{SO}_{3}$. The $\mathrm{SO}_{3}$ formed then reacts quickly with water vapour to produce sulphuric acid or depending on the meteorological conditions and availability of oxidizing substances; $\mathrm{SO}_{2}$ may be transported hundreds of kilometres before it forms sulfuric acid (Erduran and Tuncel, 2001). Another possibility is that the oxidation of trace gases emitted from biomass burning produced low-volatile condensable vapours, which nucleated in the biomass burning plume (Wu et al., 2016). Moreover, a recent study found that biomass burning can enhance the conversion of $\mathrm{NO}_{2}$ to HONO, which is one of the main sources of $\mathrm{OH}$ (Hobbs et al., 2003; Yokelson et al., 2009; Nie et al., 2015). Therefore the biomass burning mixed anthropogenic plume was expected to transport ample amount of precursor gases $\left(\mathrm{SO}_{2}\right.$ or $\left.\mathrm{H}_{2} \mathrm{SO}_{4}\right)$ initiating the nucleation upwind of the HACPL site. The spatial extension of the NPF of $1.5 \mathrm{~nm}$ diameter particles extended up to several hundred kilometres from HACPL according to the NanoMap method. In reality, the extension could be even higher than this. This is not possible to observe due to sudden interruptions in the GR of newly formed particles during NPF, and the limitations of the NanoMap method (Kristensson et al., 2014).

\section{Conclusion}

The simultaneous measurements of particle number size distribution, aerosol chemical composition and meteorology were performed at Mahabaleshwar from November 2016 to February 2017. The data was analyzed to identify the occurrence of nucleation events. Ample NPF events were observed with a frequency of $\sim 40 \%$. Certain meteorological conditions were favourable during the study period for NPF, and local and long range transported aerosol sources played a significant role in the occurrence of NPF. The main conclusions drawn from this study are listed below:

(i) All the NPF events began around 10:00-11:00 hours. Ten of the strongest NPF events observed had an average growth rate, formation rate, condensation sink and coagulation of $2.6 \pm 0.4 \mathrm{~nm} \mathrm{~h}^{-1}, 2.8 \pm 1.4 \mathrm{~cm}^{-3} \mathrm{~s}^{-1}, 2.2$ $\pm 2.9 * 10^{-2} \mathrm{~s}^{-1}$ and $1.6 \pm 1.0 \mathrm{~cm}^{-3} \mathrm{~s}^{-1}$ respectively.

(ii) Fresh anthropogenic emissions (resulting in high $\mathrm{N}_{\text {ait }}$ concentration) or unfavourable meteorology led to weak or no NPF events. On the basis of cluster analysis of backward trajectories, a concentration lower than $3 * 10^{3} \mathrm{~cm}^{-3}$ was earmarked as the threshold value of Aitken mode particles favoring nucleation. During the nonNPF event days $\mathrm{N}_{\text {ait }}$ concentrations were significantly higher.

(iii) The analysis suggested that (a) the air masses influenced by biomass burning fromnorth-east and (b) high wind speed just before the nucleation event favored nucleation at HACPL.

(iv) The growth of freshly nucleated particles persisted for $\sim 6-7$ hours and led to the significant enhancement in mass concentration of aerosol (OOA, sulfate and nitrate).

(v) The NPF events acted as the significant source of CCN with the mean percentage increment of $\sim 53 \pm 36 \%$.

(vi) NPF took place up to several hundred kilometers upwind to the north-east of HACPL.

\section{Data availability}

The data used in this study are from the data repository of HACPL, part of IITM, Pune and will be made available on request. 


\section{Acknowledgments}

Authors are grateful to all the team members of High AltitudeCloud Physics Laboratory (HACPL) of IITM. HACPL is fully funded byMinistry of Earth Sciences (MoES), Government of India, NewDelhi. The data used in this study are from the data repository of HACPL, part of IITM, Pune. Authors are thankful to the Director of IITM for his support and encouragement. Vyoma Singla extends special thanks to DST, SERB for NPDF fellowship (Fellowship number: PDF/2017/002428) and Director, ITM for providing all the facilities. Swedish research council FORMAS (project no. 2014-951) is acknowledged for support of the salary for Kristensson.

\section{Competing interests}

The authors declare that they have no conflict of interest.

\section{References}

Anderson, B. E., Grant, W. B., Gregory, G. L., Browell, E. V., Collins, J. E., Sachse, G. W., Bagwell, D. R., Hudgins, C. H., Blake, D. R. and Blake, N. J.: Aerosols from biomass burning over the tropical South Atlantic region: Distributions and impacts, J. Geophys. Res. Atmos., 101(D19), 24117-24137, doi:10.1029/96JD00717, 1996.

Andreae, M. O., Artaxo, P., Fischer, H., Freitas, S. R., Grégoire, J. M., Hansel, A., Hoor, P., Kormann, R., Krejci, R., Lange, L., Lelieveld, J., Lindinger, W., Longo, K., Peters, W., De Reus, M., Scheeren, B., Silva Dias, M. A. F., Ström, J., Van Velthoven, P. F. J. and Williams, J.: Transport of biomass burning smoke to the upper troposphere by deep convection in the equatorial region, Geophys. Res. Lett., 28(6), 951-954, doi:10.1029/2000GL012391, 2001.

Andreae, M.O., Browell, E.V., Garstang, M., Gregory, G.L., Harriss, R.C., Hill, G.F., Jacob, D.J., Pereira, M.C., Sachse, G.W., Setzer, A.W. and Dias, P.L.: Biomass-burning emissions and associated haze layers over Amazonia. J. Geophys. Res. Atmos., 93(D2), pp.1509-1527, doi:https://doi.org/10.1029/JD093iD02p01509, 1988.

Barsanti, K. C., McMurry, P. H. and Smith, J. N.: The potential contribution of organic salts to new particle growth, Atmos. Chem. Phys., 9(9), 2949-2957 doi: https://doi.org/10.5194/acp-9-2949-2009, 2009.

Creamean, J. M., Ault, A. P., Ten Hoeve, J. E., Jacobson, M. Z., Roberts, G. C., Prather, K. A., Hoeve, J. E. Ten, Jacobson, Z., Roberts, G. C. and Prather, K. A.: Measurements of Aerosol Chemistry during New Particle Formation Events at a Remote Rural Mountain Site Centre National de Recherches Météorologiques - Groupe, Environ. Sci. Technol., 45(19), 8208-8216, doi:10.1021/es103692f, 2011.

Crilley, L. R., Jayaratne, E. R., Ayoko, G. A., Miljevic, B., Ristovski, Z. and Morawska, L.: Observations on the Formation, Growth and Chemical Composition of Aerosols in an Urban Environment, Environ.Sci. Technol., 48, 6588-6596, doi:10.1021/es5019509, 2014.

Cubison, M. J., Ortega, A. M., Hayes, P. L., Farmer, D. K., Day, D., Lechner, M. J., Brune, W. H., Apel, E., Diskin, G. S., Fisher, J. A., Fuelberg, H. E., Hecobian, A., Knapp, D. J., Mikoviny, T., Riemer, D., Sachse, G. W., Sessions, W., Weber, R. J., Weinheimer, A. J., Wisthaler, A. and Jimenez, J. L.: Effects of aging on 
Dal Maso, M.: Formation and Growth of Fresh Atmospheric Aerosols Eight Years of Aerosol Size Distribution Data From SMEAR, Boreal Environ. Res., 10(October 2005), 323-336, 2005. Condensation Nuclei (CCN) in the urban background of Vienna, Atmos. Environ., 164, 289-298, doi:10.1016/j.atmosenv.2017.06.001, 2017. Emmons, L., Shinozuka, Y., Clarke, A., Zhou, J., Tomlinson, J., Collins, D. R., Knapp, D., Weinheimer, A. J., Montzka, D. D., Campos, T. and Jimenez, J. L.: Fast airborne aerosol size and chemistry measurements above Mexico City and Central Mexico during the MILAGRO campaign, Atmos. Chem. Phys., 8(14), 4027-4048, doi:10.5194/acp-8-4027-2008, 2008.

Draxler, R.R. and Rolph, G.D., 2003. HYSPLIT (HYbrid single-particle Lagrangian integrated trajectory) model access via NOAA ARL READY. NOAA Air Resources Laboratory, Silver Spring, MD. Dostupnona: http://ready. arl. noaa. gov/HYSPLIT. php (06. 06. 2010.).

Dusek, U., Frank, G. P., Hildebrandt, L., Curtius, J., Schneider, J., Walter, S., Chand, D., Drewnick, F., Particles, Science, 312(5778), 1375-1378, doi:10.1126/science.1125261, 2006.

Edwards, D. P., Emmons, L. K., Gille, J. C., Chu, A., Attié, J. L., Giglio, L., Wood, S. W., Haywood, J., Deeter, M. N., Massie, S. T., Ziskin, D. C. and Drummond, J. R.: Satellite-observed pollution from Southern Hemisphere biomass burning, J. Geophys. Res. Atmos., 111(14), 1-17, doi:10.1029/2005JD006655, 2006.

Engelhart, G. J., Hildebrandt, L., Kostenidou, E., Mihalopoulos, N., Donahue, N. M. and Pandis, S. N.: Water content of aged aerosol, Atmos. Chem. Phys., 11(3), 911-920, doi:10.5194/acp-11-911-2011, 2011.

Erduran, M.S. and Tuncel, S.G.: Gaseous and particulate air pollutants in the Northeastern Mediterranean Coast. Science of the total environment, 281(1-3), pp.205-215, doi:https://doi.org/10.1016/S00489697(01)00847-6, 2001.

Fan, J., Rosenfeld, D., Ding, Y., Leung, L. R. and Li, Z.: Potential aerosol indirect effects on atmospheric circulation and radiative forcing through deep convection, Geophys. Res. Lett., 39(9), 1-7, doi:10.1029/2012GL051851, 2012.

Fiore, A. M., Naik, V., Spracklen, D. V., Steiner, A., Unger, N., Prather, M., Bergmann, D., CameronSmith, P. J., Cionni, I., Collins, W. J., Dalsoren, S., Eyring, V., Folberth, G. A., Ginoux, P., Horowitz, L. W., Josse, B., Lamarque, J. F., MacKenzie, I. A., Nagashima, T., O’Connor, F. M., Righi, M., Rumbold, S. 

River Delta of China, Adv. Atmos. Sci., 25(3), 427-436, doi:10.1007/s00376-008-0427-4, 2008.

Gong, Y., Hu, M., Cheng, Y., Su, H., Yue, D., Liu, F., Wiedensohler, A., Wang, Z., Kalesse, H., Liu, S., $\mathrm{Wu}, \mathrm{Z}$., Xiao, K., Mi, P. and Zhang, Y.: Competition of coagulation sink and source rate: New particle formation in the Pearl River Delta of China, Atmos. Environ., 44(27), 3278-3285, doi:10.1016/j.atmosenv.2010.05.049, 2010.

Hamed, A., Korhonen, H., Sihto, S. L., Joutsensaari, J., Jrvinen, H., Petäjä, T., Arnold, F., Nieminen, T., Kulmala, M., Smith, J. N., Lehtinen, K. E. J. and Laaksonen, A.: The role of relative humidity in continental new particle formation, J. Geophys. Res. Atmos., 116(3), 1-12, doi:10.1029/2010JD014186, 2011 .

Hennigan, C. J., Westervelt, D. M., Riipinen, I., Engelhart, G. J., Lee, T., Collett, J. L., Pandis, S. N., important source of cloud condensation nuclei, Geophys. Res. Lett., 39(9), 1-5, doi:10.1029/2012GL050930, 2012.

Hobbs, P. V., Sinha, P., Yokelson, R. J., Christian, T. J., Blake, D. R., Gao, S., Kirchstetter, T. W., Novakov, T. and Pilewskie, P.: Evolution of gases and particles from a savanna fire in South Africa, J. Geophys. Res. Atmos., 108(D13), n/a-n/a, doi:10.1029/2002JD002352, 2003.

Kanawade, V. P., Tripathi, S. N., Siingh, D., Gautam, A. S., Srivastava, A. K., Kamra, A. K., Soni, V. K. and Sethi, V.: Observations of new particle formation at two distinct Indian subcontinental urban locations, Atmos. Environ., 96, 370-379, doi:10.1016/j.atmosenv.2014.08.001, 2014.

Kerminen, V. M. and Kulmala, M.: Analytical formulae connecting the "real" and the "apparent" nucleation rate and the nuclei number concentration for atmospheric nucleation events, J. Aerosol Sci., 33(4), 609-622, doi:10.1016/S0021-8502(01)00194-X, 2002.

Kerminen, V. M., Paramonov, M., Anttila, T., Riipinen, I., Fountoukis, C., Korhonen, H., Asmi, E., Laakso, L., Lihavainen, H., Swietlicki, E., Svenningsson, B., Asmi, A., Pandis, S. N., Kulmala, M. and Petäjä, T.: Cloud condensation nuclei production associated with atmospheric nucleation: A synthesis based on existing literature and new results, Atmos. Chem. Phys., 12(24), 12037-12059, doi:10.5194/acp-12-120372012, 2012.

Kivekäs, N., Carpman, J., Roldin, P., Leppä, J., O’Connor, E., Kristensson, A. and Asmi, E.: Coupling an aerosol box model with one-dimensional flow: A tool for understanding observations of new particle formation events, Tellus, Ser. B Chem. Phys. Meteorol., 68(1), doi:10.3402/tellusb.v68.29706, 2016. 
Kristensson, A., Johansson, M., Swietlicki, E., Kivekäs, N., Hussein, T., Nieminen, T. and Kulmala, M.: NanoMap: Geographical mapping of atmospheric new- particle formation through analysis of particle number size distribution and trajectory data, , 19(September), 329-342, 2014.

Kulmala, M. and Kerminen, V. M.: On the formation and growth of atmospheric nanoparticles, Atmos. Res., 90(2-4), 132-150, doi:10.1016/j.atmosres.2008.01.005, 2008.

Kulmala, M., Kontkanen, J., Junninen, H., Lehtipalo, K., Manninen, H. E., Nieminen, T., Petäjä, T., Sipilä, M., Schobesberger, S., Rantala, P., Franchin, A., Jokinen, T., Järvinen, E., Äijälä, M., Kangasluoma, J., Hakala, J., Aalto, P. P., Paasonen, P., Mikkilä, J., Vanhanen, J., Aalto, J., Hakola, H., Makkonen, U., Ruuskanen, T., Mauldin, R. L., Duplissy, J., Vehkamäki, H., Bäck, J., Kortelainen, A., Riipinen, I., Kurtén, T., Johnston, M. V., Smith, J. N., Ehn, M., Mentel, T. F., Lehtinen, K. E. J., Laaksonen, A., Kerminen, V. M. and Worsnop, D. R.: Direct observations of atmospheric aerosol nucleation, Science, 339(6122), 943946, doi:10.1126/science.1227385, 2013.

Kulmala, M., Vehkamäki, H., Petäjä, T., Dal Maso, M., Lauri, A., Kerminen, V. M., Birmili, W. and McMurry, P. H.: Formation and growth rates of ultrafine atmospheric particles: A review of observations, J. Aerosol Sci., 35(2), 143-176, doi:10.1016/j.jaerosci.2003.10.003, 2004.

Lance, S., Medina, J., Smith, J. and Nenes, A.: Mapping the operation of the DMT continuous flow CCN counter, Aerosol Sci. Technol., 40(4), 242-254, doi:10.1080/02786820500543290, 2006.

Leena, P. P., Anil Kumar, V., Dani, K. K., Sombawne, S. M., Murugavel, P. and Pandithurai, G.: Evidence of new particle formation during post monsoon season over a high-altitude site of the Western Ghats, India, Toxicol. Environ. Chem., 99(4), 652-664, doi:10.1080/02772248.2016.1274031, 2017.

Levin, E., Prenni, a, Petters, M., Kreidenweis, S., Sullivan, R., Atwood, S., Ortega, J., Demott, P. and Smith, J.: An annual cycle of size-resolved aerosol hygroscopicity at a forested site in Colorado, J. Geophys. Res., 117(D6), D06201, doi:10.1029/2011JD016854, 2012.

Li, Y., Zhang, F., Li, Z., Sun, L., Wang, Z., Li, P., Sun, Y., Ren, J., Wang, Y., Cribb, M. and Yuan, C.: Influences of aerosol physiochemical properties and new particle formation on CCN activity from observation at a suburban site of China, Atmos. Res., 188, 80-89, doi:10.1016/j.atmosres.2017.01.009, 2017.

Lihavainen, H.: Production of "potential" cloud condensation nuclei associated with atmospheric newparticle formation in northern Finland, J. Geophys. Res., 108, 1-8, doi:10.1029/2003JD003887, 2003.

Ma, N., Zhao, C., Tao, J., Wu, Z., Kecorius, S., Wang, Z., Groß, J., Liu, H., Bian, Y., Kuang, Y., Teich, M., Spindler, G., Muller, K., Van Pinxteren, D., Herrmann, H., Hu, M. and Wiedensohler, A.: Variation of CCN activity during new particle formation events in the North China Plain, Atmos. Chem. Phys., 16(13), 85938607, doi:10.5194/acp-16-8593-2016, 2016. 

altitude site in Western Ghats, India, Atmos. Environ., 180(February), 79-92, doi:10.1016/j.atmosenv.2018.02.048, 2018. Phys., 14(16), 8841-8848, doi:10.5194/acp-14-8841-2014, 2014.

Nie, W., Ding, A. J., Xie, Y. N., Xu, Z., Mao, H., Kerminen, V. M., Zheng, L. F., Qi, X. M., Huang, X., Yang, X. Q., Sun, J. N., Herrmann, E., Petäjä, T., Kulmala, M. and Fu, C. B.: Influence of biomass burning plumes on HONO chemistry in eastern China, Atmos. Chem. Phys., 15(3), 1147-1159, doi:10.5194/acp-151147-2015, 2015.

Paatero, P. and Tapper, U.: Positive matrix factorization: A non???negative factor model with optimal utilization of error estimates of data values, Environmetrics, 5(2), 111-126, doi:10.1002/env.3170050203, 1994.

Petit, J. E., Favez, O., Albinet, A. and Canonaco, F.: A user-friendly tool for comprehensive evaluation of the geographical origins of atmospheric pollution: Wind and trajectory analyses, Environ. Model. Softw., 88, 183-187, doi:10.1016/j.envsoft.2016.11.022, 2017.

Pierce, J. R. and Adams, P. J.: Uncertainty in global CCN concentrations from uncertain aerosol nucleation Pikridas, M., Riipinen, I., Hildebrandt, L., Kostenidou, E., Manninen, H., Mihalopoulos, N., Kalivitis, N., eastern Mediterranean, J. Geophys. Res. Atmos., 117(12), 1-14, doi:10.1029/2012JD017570, 2012.

Riipinen, I., Sihto, S., Kulmala, M., Arnold, F., Maso, M. D., Birmili, W., Saarnio, K. and Teinil, K.: Connections between atmospheric sulphuric acid and new particle formation during QUEST III - IV campaigns in Heidelberg and Hyytiala, Atmos. Chem. Phys., 7, 1899-1914, doi:10.5194/acpd-6-108372006, 2007.

Roberts, G. C. and Nenes, A.: A continuous-flow streamwise thermal-gradient CCN chamber for atmospheric measurements, Aerosol Sci. Technol., 39(3), 206-221, doi:10.1080/027868290913988, 2005.

Rose, D., Nowak, A., Achtert, P., Wiedensohler, A., Hu, M., Shao, M., Zhang, Y., Andreae, M. O. and Pöschl, U.: Cloud condensation nuclei in polluted air and biomass burning smoke near the mega-city Guangzhou, China - Part 1: Size-resolved measurements and implications for the modeling of aerosol particle hygroscopicity and CCN activity, Atmos. Chem. Phys., 10(7), 3365-3383, doi:10.5194/acp-103365-2010, 2010.

Rosenfeld, D., Lohmann, U., Raga, G. B., O’Dowd, C. D., Kulmala, M., Fuzzi, S., Reissell, A. and Andreae, M. O.: Flood or drought: How do aerosols affect precipitation?, Science, 321(5894), 1309-1313, doi:10.1126/science.1160606, 2008. 

http://doi.org/10.1136/thorax.58.12.1012, 2003. ambient aerosol particles in Southeast Asia during hazy and nonhazy days, J. Geophys. Res. Atmos., 111(10), 1-12, doi:10.1029/2005JD006180, 2006. and Zhou, H.: Spatial distribution and occurrence probability of regional new particle formation events in eastern China, Atmos. Chem. Phys., 18(2), 587-599, doi:10.5194/acp-18-587-2018, 2018. aerosols in $\mathrm{CCN}$ activation and closure over a rural background site in Western Ghats, India, Atmos.

Skrabalova, L., Zikova, N. and Zdimal, V.: Shrinkage of newly formed particles in an urban environment,

Spracklen, D. V., Carslaw, K. S., Kulmala, M., Kerminen, V. M., Sihto, S. L., Riipinen, I., Merikanto, J., Mann, G. W., Chipperfield, M. P., Wiedensohler, A., Birmili, W. and Lihavainen, H.: Contribution of particle formation to global cloud condensation nuclei concentrations, Geophys. Res. Lett., 35(6), 1-5, doi:10.1029/2007GL033038, 2008.

Stanier, C. O., Khlystov, A. Y. and Pandis, S. N.: Nucleation events during the Pittsburgh Air Quality Study: Description and relation to key meteorological, gas phase, and aerosol parameters, Aerosol Sci. Technol., 38(SUPPL. 1), 253-264, doi:10.1080/02786820390229570, 2004.

Stier, P., Seinfeld, J. H., Kinne, S. and Boucher, O.: Aerosol absorption and radiative forcing, Atmos. Chem. Phys., 7(19), 5237-5261, doi:10.5194/acp-7-5237-2007, 2007.

Väänänen, R., Krejci, R., Manninen, H. E., Manninen, A., Lampilahti, J., Buenrostro Mazon, S., Nieminen, T., Yli-Juuti, T., Kontkanen, J., Asmi, A., Aalto, P. P., Keronen, P., Pohja, T., O\&apos;Connor, E., Kerminen, V.-M., Petäjä, T. and Kulmala, M.: Vertical and horizontal variation of aerosol number size distribution in the boreal environment, Atmos. Chem. Phys. Discuss., (July), 1-43, doi:10.5194/acp-2016$556,2016$.

Vehkamäki, H. and Riipinen, I.: Thermodynamics and kinetics of atmospheric aerosol particle formation and growth, Chem. Soc. Rev., 41(15), 5160-5173, doi:10.1039/c2cs00002d, 2012.

Wang, Z. B., Hu, M., Sun, J. Y., Wu, Z. J., Yue, D. L., Shen, X. J., Zhang, Y. M., Pei, X. Y., Cheng, Y. F. and Wiedensohler, A.: Characteristics of regional new particle formation in urban and regional background environments in the North China Plain, Atmos. Chem. Phys., 13(24), 12495-12506, doi:10.5194/acp-1312495-2013, 2013. 
Wiedensohler, A., Cheng, Y. F., Nowak, A., Wehner, B., Achtelt, P., Berghof, M., Birmili, W., Wu, Z. J., Hu, M., Zhu, T., Takegawa, N., Kita, K., Kondo, Y., Lou, S. R., Hofeumahaus, A., Holland, F., Wahner, A., Gunthe, S. S., Rose, D., Su, H. and Pöschl, U.: Rapid aerosol particle growth and increase of cloud condensation nucleus activity by secondary aerosol formation and condensation: A case study for regional air pollution in northeastern China, J. Geophys. Res. Atmos., 114(8), 1-13, doi:10.1029/2008JD010884, 2009.

Wu, Z., Hu, M., Liu, S., Wehner, B., Bauer, S., Ma ßLing, A., Wiedensohler, A., Petäjä, T., Dal Maso, M. and Kulmala, M.: New particle formation in Beijing, China: Statistical analysis of a 1-year data set, J. Geophys. Res. Atmos., 112(9), 1-10, doi:10.1029/2006JD007406, 2007.

Wu, Z., Zheng, J., Wang, Y., Shang, D., Du, Z., Zhang, Y. and Hu, M.: Chemical and physical properties of biomass burning aerosols and their CCN activity: A case study in Beijing, China, Sci. Total Environ., 579, 1260-1268, doi:10.1016/j.scitotenv.2016.11.112, 2017.

Xie, Y., Ding, A., Nie, W., Mao, H., Qi, X., Huang, X., Xu, Z., Kerminen, V. M., Petäjä, T., Chi, X., Virkkula, A., Boy, M., Xue, L., Guo, J., Sun, J., Yang, X., Kulmala, M. and Fu, C.: Enhanced sulfate formation by nitrogen dioxide: Implications from in-situ observations at the SORPES station, J. Geophys. Res., 120(24), 12,679-12,694, doi:10.1002/2015JD023607, 2015.

Yokelson, R. J., Crounse, J. D., DeCarlo, P. F., Karl, T., Urbanski, S., Atlas, E., Campos, T., Shinozuka, Y., Kapustin, V., Clarke, A. D., Weinheimer, A., Knapp, D. J., Montzka, D. D., Holloway, J., Weibring, P., Flocke, F., Zheng, W., Toohey, D., Wennberg, P. O., Wiedinmyer, C., Mauldin, L., Fried, A., Richter, D., Walega, J., Jimenez, J. L., Adachi, K., Buseck, P. R., Hall, S. R. and Shetter, R.: Emissions from biomass burning in the Yucatan, Atmos. Chem. Phys., 9(15), 5785-5812, doi:10.5194/acp-9-5785-2009, 2009.

Yue, D., Hu, M., Wu, Z., Wang, Z., Guo, S., Wehner, B., Nowak, A., Achtert, P., Wiedensohler, A., Jung, J., Kim, Y. J. and Liu, S.: Characteristics of aerosol size distributions and new particle formation in the summer in Beijing, J. Geophys. Res. Atmos., 114(14), 1-13, doi:10.1029/2008JD010894, 2009.

Yue, D. L., Hu, M., Zhang, R. Y., Wang, Z. B., Zheng, J., Wu, Z. J., Wiedensohler, A., He, L. Y., Huang, X. F. and Zhu, T.: The roles of sulfuric acid in new particle formation and growth in the mega-city of Beijing, Atmos. Chem. Phys., 10(10), 4953-4960, doi:10.5194/acp-10-4953-2010, 2010.

Yue, D. L., Hu, M., Zhang, R. Y., Wu, Z. J., Su, H., Wang, Z. B., Peng, J. F., He, L. Y., Huang, X. F., Gong, Y. G. and Wiedensohler, A.: Potential contribution of new particle formation to cloud condensation nuclei in Beijing, Atmos. Environ., 45(33), 6070-6077, doi:10.1016/j.atmosenv.2011.07.037, 2011.

Zhang, Q., Stanier, C. O., Canagaratna, M. R., Jayne, J. T., Worsnop, D. R., Pandis, S. N. and Jimenez, J. L.: Insights into the chemistry of new particle formation and growth events in Pittsburgh based on aerosol mass spectrometry, Environ. Sci. Technol., 38(18), 4797-4809, doi:Doi 10.1021/Es035417u, 2004. 
Atmos. Chem. Phys. Discuss., https://doi.org/10.5194/acp-2018-637

Manuscript under review for journal Atmos. Chem. Phys.

Discussion started: 2 July 2018

(c) Author(s) 2018. CC BY 4.0 License.
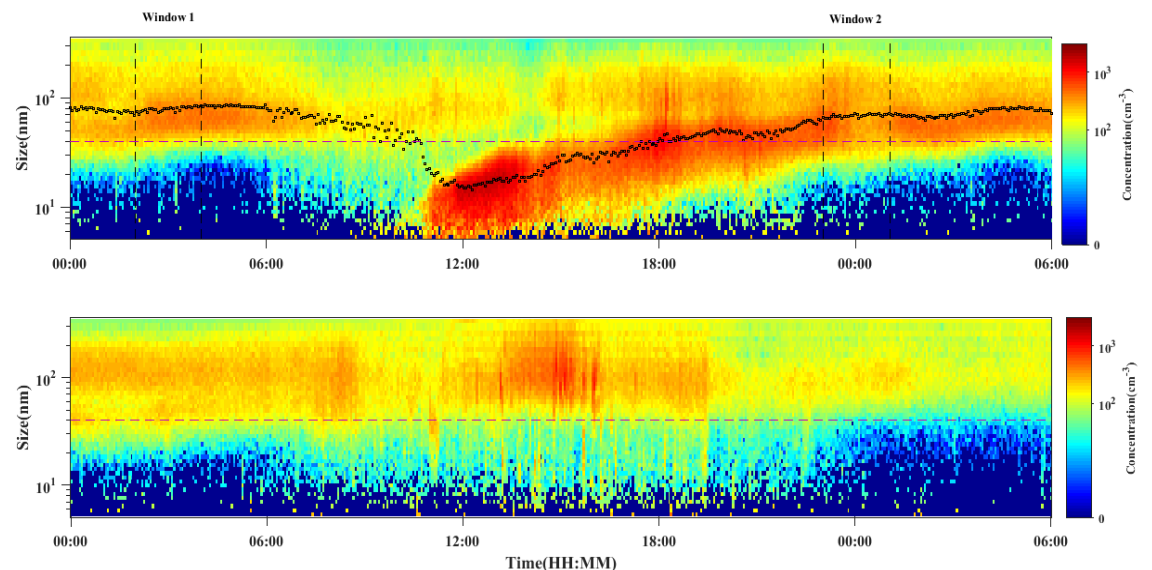

Figure 1: The spectrum of the particle number size distribution on a strong NPF day - 12th December 2016 (upper panel) and a non-NPF day - 14th December 2016 (lower panel). Window 1 and Window 2 represents the stable atmospheric conditions before and after the nucleation started, respectively. The black dotted line in the upper panel represents the geometric mean diameter of particles. The horizontal dashed line in both the panels represents the diameter of particles at $40 \mathrm{~nm}$.
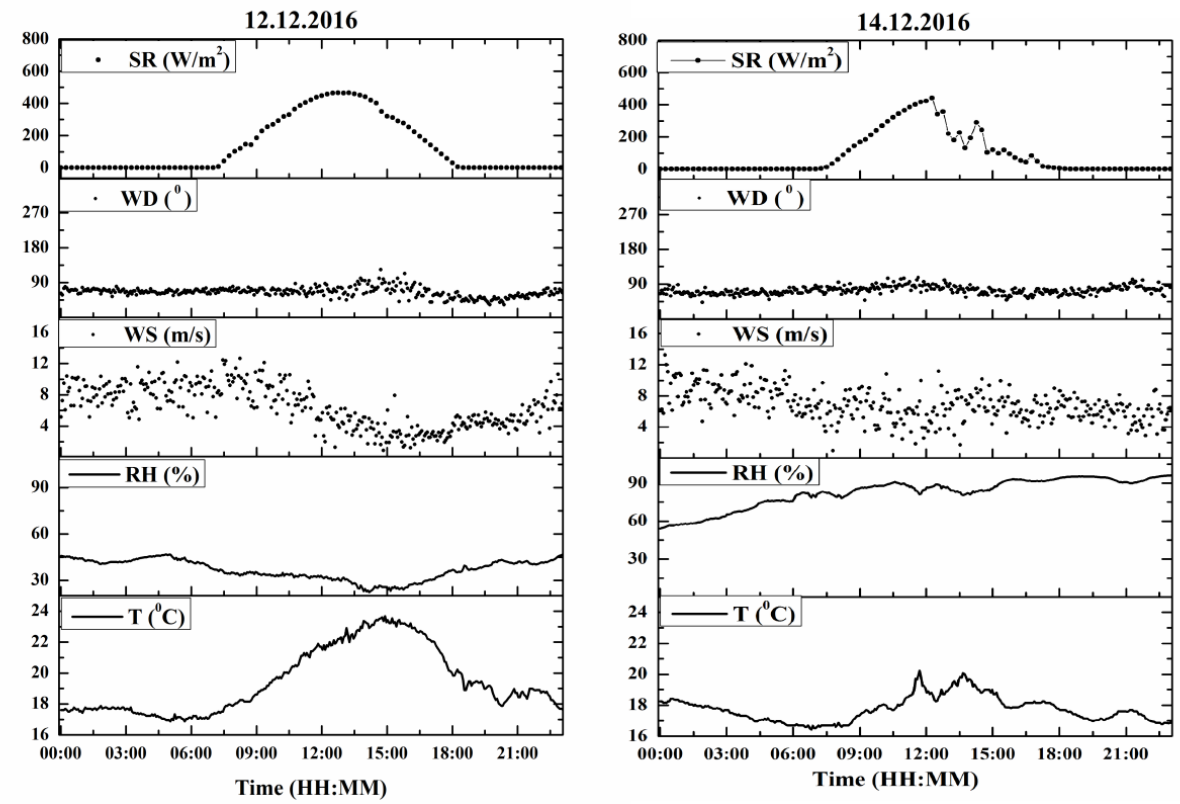

Figure 2: Diurnal variation of meteorological conditions - Solar radiation (SR), Wind direction (WD), Wind speed (WS), Relative Humidity (RH) and Temperature (T) on the special case NPF day (left panel, December $12,2016)$ and the non-NPF day (right panel, December 14, 2016). 
Atmos. Chem. Phys. Discuss., https://doi.org/10.5194/acp-2018-637

Manuscript under review for journal Atmos. Chem. Phys.
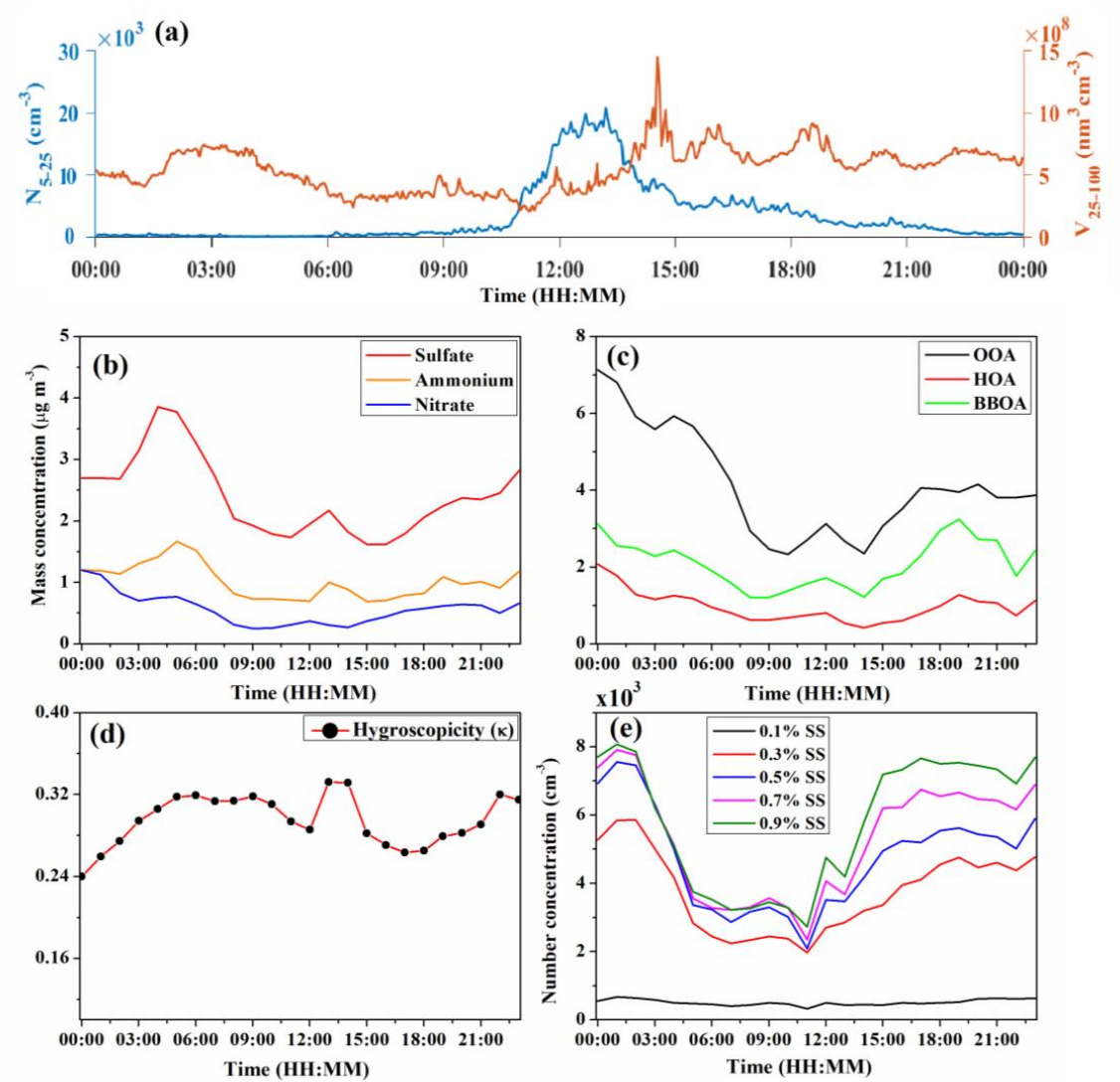

Figure 3: Particle properties during the strong NPF event day on December 12, 2016. Diurnal Variation of (a) nucleation mode number concentration and aitken mode volume concentration (b) mass concentration of secondary inorganic aerosol species (c) mass concentration of secondary organic aerosol species $(\mathrm{OOA}=$ oxygenated organic aerosol, $\mathrm{HOA}=$ hydrogenated organic aerosol, $\mathrm{BBOA}=$ biomass burning organic aerosol) (d) calculated hygroscopicity and (e) CCN number concentration at five supersaturations $-0.1 \%, 0.3 \%, 0.5 \%$, $7740.7 \%$ and $0.9 \%$. 
Atmos. Chem. Phys. Discuss., https://doi.org/10.5194/acp-2018-637

Manuscript under review for journal Atmos. Chem. Phys.
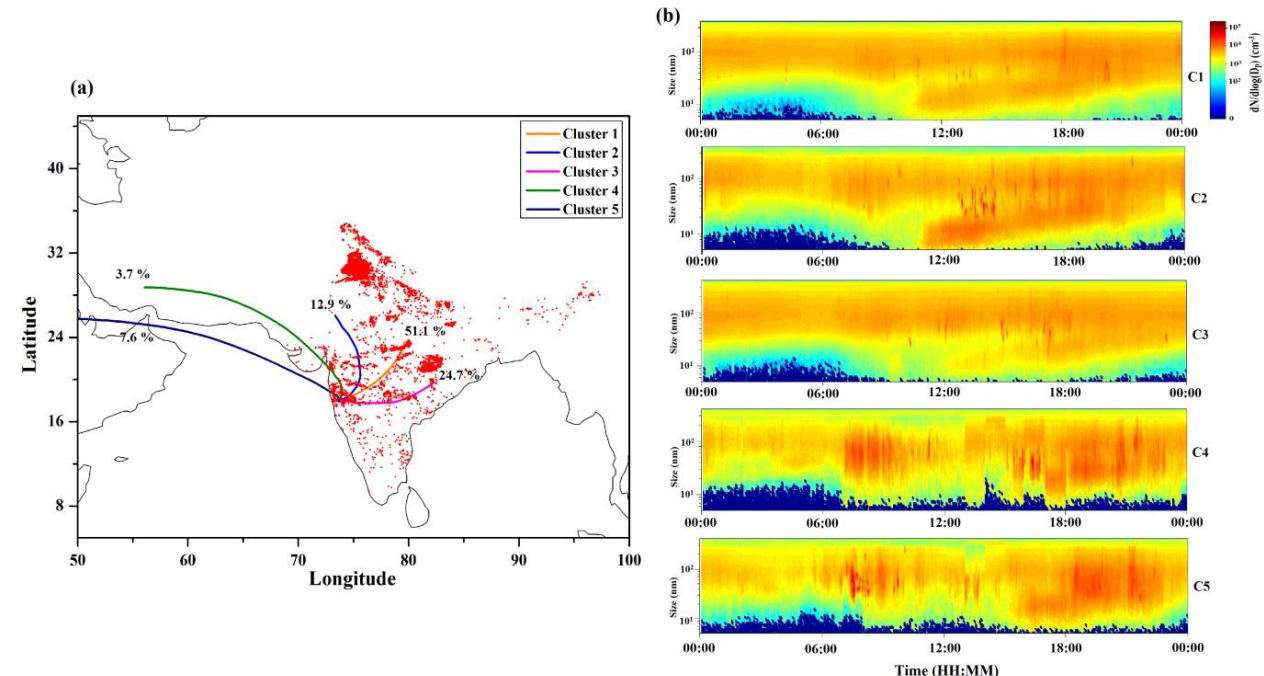

Figure 4: Results of $120 \mathrm{~h}$ air mass backward trajectories at $100 \mathrm{~m}$ above ground level during the study period (November 2016 to February 2017). Left Panel (a) - The mean trajectories of each cluster obtained through cluster analysis. Red dots represent the fire hotspots as identified by MODIS. Right Panel (b) - The spectrum of average particle number size distribution corresponding to each mean cluster.

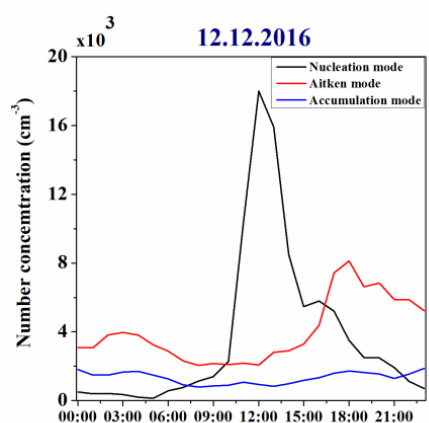

Time (HH:MM)

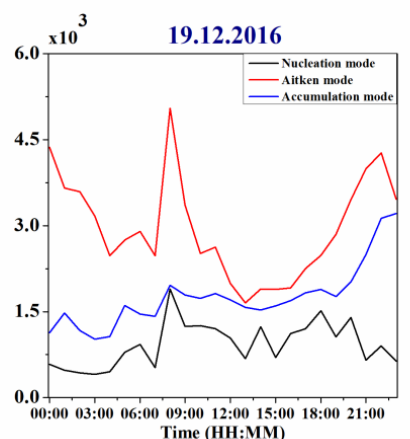

Time (HH:MM)

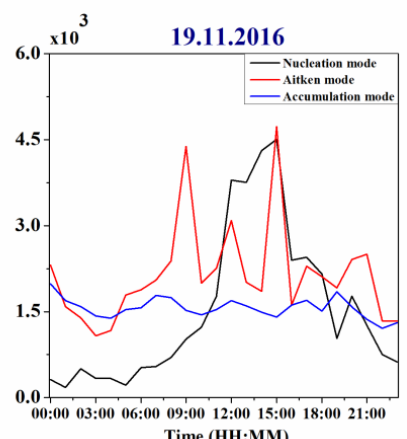

Time (HH:MM)

Figure 5: Diurnal Variation of particle number concentration in three modes - nucleation, aitken and accumulation mode for a NPF day $-12^{\text {th }}$ December 2016, a non-NPF day - $19^{\text {th }}$ December 2016 and a weak-NPF day - $19^{\text {th }}$ November 2016. 
Atmos. Chem. Phys. Discuss., https://doi.org/10.5194/acp-2018-637

Manuscript under review for journal Atmos. Chem. Phys.

Discussion started: 2 July 2018

(c) Author(s) 2018. CC BY 4.0 License.
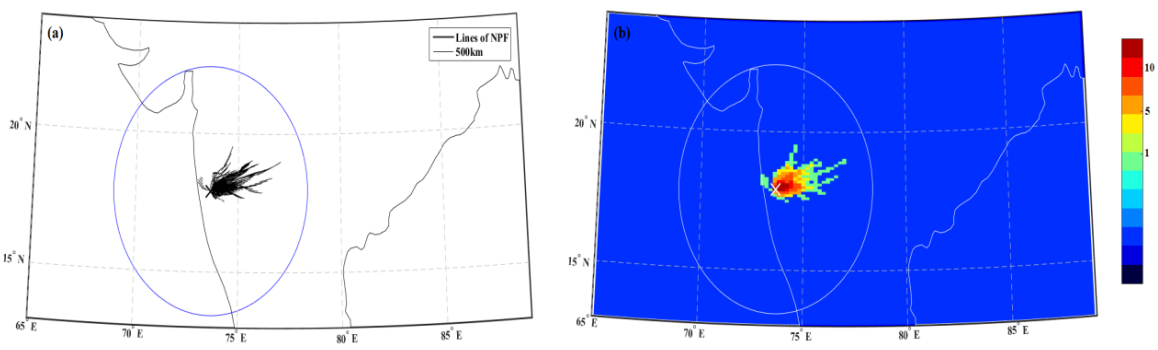

Figure 6: NanoMap results: Left Panel (a) - Black Lines represent the formation of $1.5 \mathrm{~nm}$ diameter particles. Right Panel (b) - The frequency of NPF events at $1.5 \mathrm{~nm}$ diameter, with a grid resolution of $0.1 \times 0.2$ degrees for latitude and longitude, respectively. The blue and white ovals limit the horizontal dimension of $500 \mathrm{~km}$ radius from the sampling site. 
Table 1: Summary of new particle formation events (strong event days) observed during November 2016 to February 2017. The start and end time were identified based on the change in GMD of nucleation mode particles. The $\mathrm{F}_{\text {coag }}$ and $\mathrm{J}_{5}$ were calculated at the time of NPF formation. The CS corresponds to the time period $\sim 1$ hour before the start of NPF at $5.14 \mathrm{~nm}$ diameter. The GMD of nucleation mode particles $(5-25 \mathrm{~nm})$ was used to calculate the GR.

\begin{tabular}{|c|c|c|c|c|c|c|}
\hline Date & Start Time & End Time & $\mathrm{J}_{5}\left(\mathrm{~cm}^{-3} \mathrm{~s}^{-1}\right)$ & $\begin{array}{c}\mathbf{F}_{\text {coag }} \\
\left(\mathrm{cm}^{-3} \mathrm{~s}^{-1}\right)\end{array}$ & $\begin{array}{c}\mathrm{CS} \\
\left(* 10^{-2} \mathbf{s}^{-1}\right)\end{array}$ & $\begin{array}{c}\mathbf{G R}_{5-25} \\
\left(\mathrm{~nm} \mathrm{~h}^{-1}\right)\end{array}$ \\
\hline \multicolumn{7}{|c|}{ NPF Days } \\
\hline $8 \mathrm{Nov}$ & 11:00 & 18:00 & 4.9 & 3.4 & 2.1 & 2.3 \\
\hline 9 Nov & $10: 00$ & $17: 00$ & 6.6 & 5.2 & 2.0 & 2.4 \\
\hline 10 Nov & 11:00 & $17: 00$ & 6.9 & 5.4 & 2.2 & 2.4 \\
\hline $12 \mathrm{Nov}$ & 11:00 & $17: 00$ & 3.9 & 3.0 & 2.3 & 2.5 \\
\hline $18 \mathrm{Nov}$ & $10: 00$ & $16: 00$ & 7.3 & 6.3 & 2.2 & 3.3 \\
\hline 2 Dec & $10: 00$ & $17: 00$ & 2.0 & 1.5 & 2.1 & 2.2 \\
\hline 12 Dec & $11: 00$ & $18: 00$ & 6.6 & 5.1 & 2.0 & 2.5 \\
\hline 13 Dec & $10: 00$ & $16: 00$ & 5.2 & 4.4 & 2.9 & 2.3 \\
\hline 17 Feb & $12: 00$ & 18:00 & 2.4 & 1.8 & 2.1 & 3.0 \\
\hline 18 Feb & 11:00 & $18: 00$ & 4.1 & 3.3 & 2.5 & 2.9 \\
\hline \multicolumn{7}{|c|}{ Non-NPF Days } \\
\hline 14 Dec & - & & - & - & 4.4 & - \\
\hline 15 Dec & - & & - & - & 4.2 & - \\
\hline
\end{tabular}

Table 2: Summary of NPF event days qualifying the criterion mentioned in section 4.3. POA here refers to the sum of HOA and BBOA. The information on HOA and BBOA was obtained by using Positive Matrix Factorization. All the parameters listed below are calculated at $0.52 \%$ SS.

\begin{tabular}{|c|c|c|c|c|}
\hline Date & $\boldsymbol{\Delta C C N}$ & $\boldsymbol{\Delta C C N} / \mathbf{C N}$ & $\boldsymbol{\Delta C C N / P O A}$ & $\boldsymbol{\Delta C C N / N R - P M}$ \\
\hline $\mathbf{0 7 . 1 1 . 1 6}$ & $40 \%$ & $24 \%$ & $61 \%$ & $99 \%$ \\
\hline $\mathbf{0 8 . 1 1 . 1 6}$ & $29 \%$ & $37 \%$ & $65 \%$ & $44 \%$ \\
\hline $\mathbf{0 9 . 1 1 . 1 6}$ & $43 \%$ & $45 \%$ & $77 \%$ & $23 \%$ \\
\hline $\mathbf{1 0 . 1 1 . 1 6}$ & $19 \%$ & $15 \%$ & $32 \%$ & $11 \%$ \\
\hline $\mathbf{1 8 . 1 1 . 1 6}$ & $21 \%$ & $34 \%$ & $-30 \%$ & $25 \%$ \\
\hline $\mathbf{2 3 . 1 1 . 1 6}$ & $4 \%$ & $29 \%$ & $-20 \%$ & $13 \%$ \\
\hline $\mathbf{1 1 . 1 2 . 1 6}$ & $75 \%$ & $13 \%$ & $2 \%$ & $31 \%$ \\
\hline $\mathbf{1 2 . 1 2 . 1 6}$ & $93 \%$ & $26 \%$ & $-18 \%$ & $11 \%$ \\
\hline $\mathbf{1 3 . 1 2 . 1 6}$ & $33 \%$ & $38 \%$ & $58 \%$ & $10 \%$ \\
\hline $\mathbf{1 8 . 1 2 . 1 6}$ & $5 \%$ & $13 \%$ & $8 \%$ & $12 \%$ \\
\hline $\mathbf{0 3 . 0 1 . 1 7}$ & $51 \%$ & $28 \%$ & $-12 \%$ & $44 \%$ \\
\hline $\mathbf{2 4 . 0 1 . 1 7}$ & $76 \%$ & $11 \%$ & $-29 \%$ & $8 \%$ \\
\hline $\mathbf{2 5 . 0 1 . 1 7}$ & $58 \%$ & $24 \%$ & $-31 \%$ & $23 \%$ \\
\hline
\end{tabular}


Atmos. Chem. Phys. Discuss., https://doi.org/10.5194/acp-2018-637

Manuscript under review for journal Atmos. Chem. Phys.

Discussion started: 2 July 2018

(c) Author(s) 2018. CC BY 4.0 License.

834 Table 3: Summary of secondary aerosol components, both organics and inorganics. The mass 835 concentration is represented as mean \pm standard deviation $\left(\mu \mathrm{g} \mathrm{m}^{-3}\right)$ for the five clusters.

\begin{tabular}{|c|c|c|c|c|c|c|}
\hline Cluster & Sulfate & Nitrate & Ammonium & HOA & BBOA & OOA \\
\hline C1 & $3.5 \pm 3.1$ & $1.0 \pm 1.0$ & $1.5 \pm 1.2$ & $0.9 \pm 1.3$ & $2.1 \pm 2.4$ & $4.0 \pm 2.7$ \\
\hline C2 & $2.9 \pm 1.7$ & $0.9 \pm 1.0$ & $1.0 \pm 0.8$ & $0.7 \pm 1.3$ & $1.6 \pm 2.2$ & $3.1 \pm 2.1$ \\
\hline C3 & $3.4 \pm 3.0$ & $1.1 \pm 0.9$ & $1.5 \pm 1.2$ & $0.8 \pm 1.1$ & $1.5 \pm 2.2$ & $3.5 \pm 2.6$ \\
\hline C4 & $1.2 \pm 0.9$ & $0.5 \pm 0.4$ & $0.6 \pm 0.4$ & $0.8 \pm 1.8$ & $1.3 \pm 1.8$ & $1.7 \pm 1.1$ \\
\hline C5 & $1.4 \pm 1.7$ & $1.0 \pm 1.1$ & $1.1 \pm 0.8$ & $0.6 \pm 0.9$ & $1.3 \pm 1.3$ & $2.0 \pm 1.4$ \\
\hline
\end{tabular}

836

837 